\title{
Application of the Method of Coprecipitation of Salts to Obtain Zinc Orthostannate
}

\author{
Dmitry A. Antonov ${ }^{1, *}$, Valery V. Anisimov ${ }^{1}$, and Mikhail A. Tarasenko ${ }^{1}$ \\ ${ }^{1}$ D. I. Mendeleev University of Chemical Technology of Russia, 125047, Moscow, Miusskaya square, \\ 9, Russia
}

\begin{abstract}
The effect of the temperature treatment of compounds obtained by the method of co-precipitation of zinc and tin (IV) salts on the synthesis of highly dispersed zinc orthostannate in the temperature range $800-$ $1300{ }^{\circ} \mathrm{C}$ was studied. The effect of the nonstoichiometric ratio of the components in the initial composition on the phase composition of the resulting zinc orthostannate was considered. The phase composition of the obtained powders is presented according to the data of X-ray phase analysis. Demonstrated chemical reactions occurring during the experiment.
\end{abstract}

\section{Introduction}

$\mathrm{ZnO}$ and $\mathrm{SnO}_{2}$ are multifunctional materials that are used as gas sensors, catalysts and their carriers, varistors and transparent conductive layers. Composites and compounds formed in the system of these oxides are promising semiconductors and can be used in highly efficient solar energy converters. [1-2]. Zinc orthostannate $\mathrm{Zn}_{2} \mathrm{SnO}_{4}$ is a stable compound with a spinel structure, is an n-type semiconductor and has excellent electrophysical properties: band gap energy $3.4-3.6 \mathrm{eV}$, electron mobility $10-15 \mathrm{~cm} /(\mathrm{V} \cdot \mathrm{s})$, high specific conductivity $10^{4} \mathrm{Ohm}^{-1} \cdot \mathrm{m}^{-1}$. Compared to simple zinc and tin oxides, it has good optical properties, transparency, surface smoothness and high scratch resistance. There are various methods for producing zinc orthostannate, which include: self-propagating high-temperature synthesis, hydrothermal synthesis, solid-phase synthesis from oxides, as well as electrochemical and various chemical methods. [3-4]. Of the chemical methods for the preparation of orthostannate, one can distinguish the method of co-precipitation of salts and the sol-gel method with further heat treatment of the obtained compounds. [5]. These methods are quite flexible and not labor-intensive; they make it possible to obtain nanosized highly dispersed sintering-active powder with a reduced synthesis temperature.

The presented study demonstrates the synthesis of zinc orthostannate by the method of coprecipitation of zinc and tin (IV) salts with subsequent heat treatment of the obtained compounds in the temperature range $800-1300{ }^{\circ} \mathrm{C}$.

\footnotetext{
* Corresponding author: dimantonov@muctr.ru
} 


\section{Experimental part}

The following compounds were used as starting components: tin (IV) chloride pentahydrate $\mathrm{SnCl}_{4} \cdot 5 \mathrm{H}_{2} \mathrm{O}$, zinc acetate dihydrate $\mathrm{Zn}\left(\mathrm{CH}_{3} \mathrm{COO}\right)_{2} \cdot 2 \mathrm{H}_{2} \mathrm{O}$, as well as ammonium carbonate $\left(\mathrm{NH}_{4}\right)_{2} \mathrm{CO}_{3}$, which is a precipitant in the ongoing reactions; all substances were of analytical grade.

The salts of zinc and tin (IV) were taken in such an amount that, after firing, their ratio was $2,2.5$, and 3 to 1 .

To implement the coprecipitation method, separately prepared aqueous solutions of tin (IV) and zinc salts were mixed, then an aqueous solution of $\left(\mathrm{NH}_{4}\right)_{2} \mathrm{CO}_{3}$ with a $10 \%$ excess was gradually added, which should ensure complete precipitation of metal compounds, the $\mathrm{pH}$ value was $7-8$. The suspension was dried at a temperature of $80^{\circ} \mathrm{C}$ until moisture was completely removed, after which, for greater homogenization, the powder was mechanically crushed and mixed.

The synthesis of zinc orthostannate was carried out by firing the zinc and tin (IV) compounds obtained during the experiment in air in the temperature range $800-1300{ }^{\circ} \mathrm{C}$ for a ratio of 2: 1 and at a temperature of $1200{ }^{\circ} \mathrm{C}$ for a ratio of 2.5: 1 and 3: 1 , exposure at the maximum temperature in all cases was $2 \mathrm{~h}$, the heating rate was $2 \mathrm{deg} / \mathrm{min}$.

The phase composition of the samples was studied using a DRON-3M X-ray unit, emitting - $\mathrm{CuK} \alpha$, detector - scintillation counter. To identify crystalline phases, the Joint Committee on Powoler Diffaction Standarts international card index was used.

\section{Results and discussion}

The temperature range for the synthesis of orthostannate was selected in accordance with the literature data, according to which its formation begins at a temperature of $900-950^{\circ} \mathrm{C}$, if chemical methods were used to obtain the initial components. Using the coprecipitation method can reduce the energy required, since zinc ortostannate direct synthesis of $\mathrm{ZnO}$ and $\mathrm{SnO}_{2}$ begins at $1300{ }^{\circ} \mathrm{C}[4]$.

Throughout all experiments, a solution of ammonium bicarbonate obtained from ammonium carbonate was used (1). Use of $\left(\mathrm{NH}_{4}\right)_{2} \mathrm{CO}_{3}$ as precipitant is justified, since the side of the compound formed in the reaction are easily removed during the thermal treatment, which is difficult when using alkalis.

$$
\left(\mathrm{NH}_{4}\right)_{2} \mathrm{CO}_{3}+\mathrm{H}_{2} \mathrm{O} \leftrightarrow \mathrm{NH}_{4} \mathrm{HCO}_{3}+\mathrm{NH}_{4} \mathrm{OH}
$$

Hydrolysis of tin (IV) chloride and its further transition to tin (IV) oxide during heat treatment occurs with the formation of $\alpha$-stanic acid (2-3):

$$
\begin{gathered}
\mathrm{SnCl}_{4}+4 \mathrm{NH}_{4} \mathrm{HCO}_{3}+(\mathrm{n}-1) \mathrm{H}_{2} \mathrm{O} \rightarrow \mathrm{H}_{2} \mathrm{SnO}_{3} \cdot \mathrm{n} \mathrm{H}_{2} \mathrm{O} \downarrow+4 \mathrm{NH}_{4} \mathrm{Cl}+4 \mathrm{CO}_{2} \uparrow \\
\mathrm{H}_{2} \mathrm{SnO}_{3} \cdot \mathrm{n} \mathrm{H}_{2} \mathrm{O} \rightarrow \mathrm{SnO}_{2}+(\mathrm{n}+1) \mathrm{H}_{2} \mathrm{O}
\end{gathered}
$$

Hydrolysis of zinc acetate proceeds with the formation of tetraamminezinc hydroxide, which, when heated, decomposes to zinc hydroxide, and then to zinc oxide (4-6):

$$
\begin{gathered}
\mathrm{Zn}\left(\mathrm{CH}_{3} \mathrm{COO}\right)_{2}+3 \mathrm{NH}_{4} \mathrm{HCO}_{3} \rightarrow\left[\mathrm{Zn}\left(\mathrm{NH}_{3}\right)_{4}\right](\mathrm{OH})_{2}+2 \mathrm{CH}_{3} \mathrm{COONH}_{4}+3 \mathrm{CO}_{2} \uparrow+\mathrm{H}_{2} \mathrm{O} \\
{\left[\mathrm{Zn}\left(\mathrm{NH}_{3}\right)_{4}\right](\mathrm{OH})_{2} \rightarrow \mathrm{Zn}(\mathrm{OH})_{2}+4 \mathrm{NH}_{3} \uparrow} \\
\mathrm{Zn}(\mathrm{OH})_{2} \rightarrow \mathrm{ZnO}+\mathrm{H}_{2} \mathrm{O}
\end{gathered}
$$


According to X-ray diffraction peaks characteristic of zinc ortostannata phase (7) start to appear at $900{ }^{\circ} \mathrm{C}$ and become more intense to $1300{ }^{\circ} \mathrm{C}$, in turn, the intensity of the peaks corresponding to tin (IV) oxide gradually decreases (fig. 1). The presence of tin oxide in the final samples can be associated with the reaction of the formation of zinc metastannate at lower temperatures, and its further transition to zinc orthostannate (8-9).

$$
\begin{aligned}
& 2 \mathrm{ZnO}+\mathrm{SnO}_{2} \rightarrow \mathrm{Zn}_{2} \mathrm{SnO}_{4} \\
& \mathrm{ZnO}+\mathrm{SnO}_{2} \rightarrow \mathrm{ZnSnO}_{3} \\
& 2 \mathrm{ZnSnO}_{3} \rightarrow \mathrm{Zn}_{2} \mathrm{SnO}_{4}+\mathrm{SnO}_{2}
\end{aligned}
$$

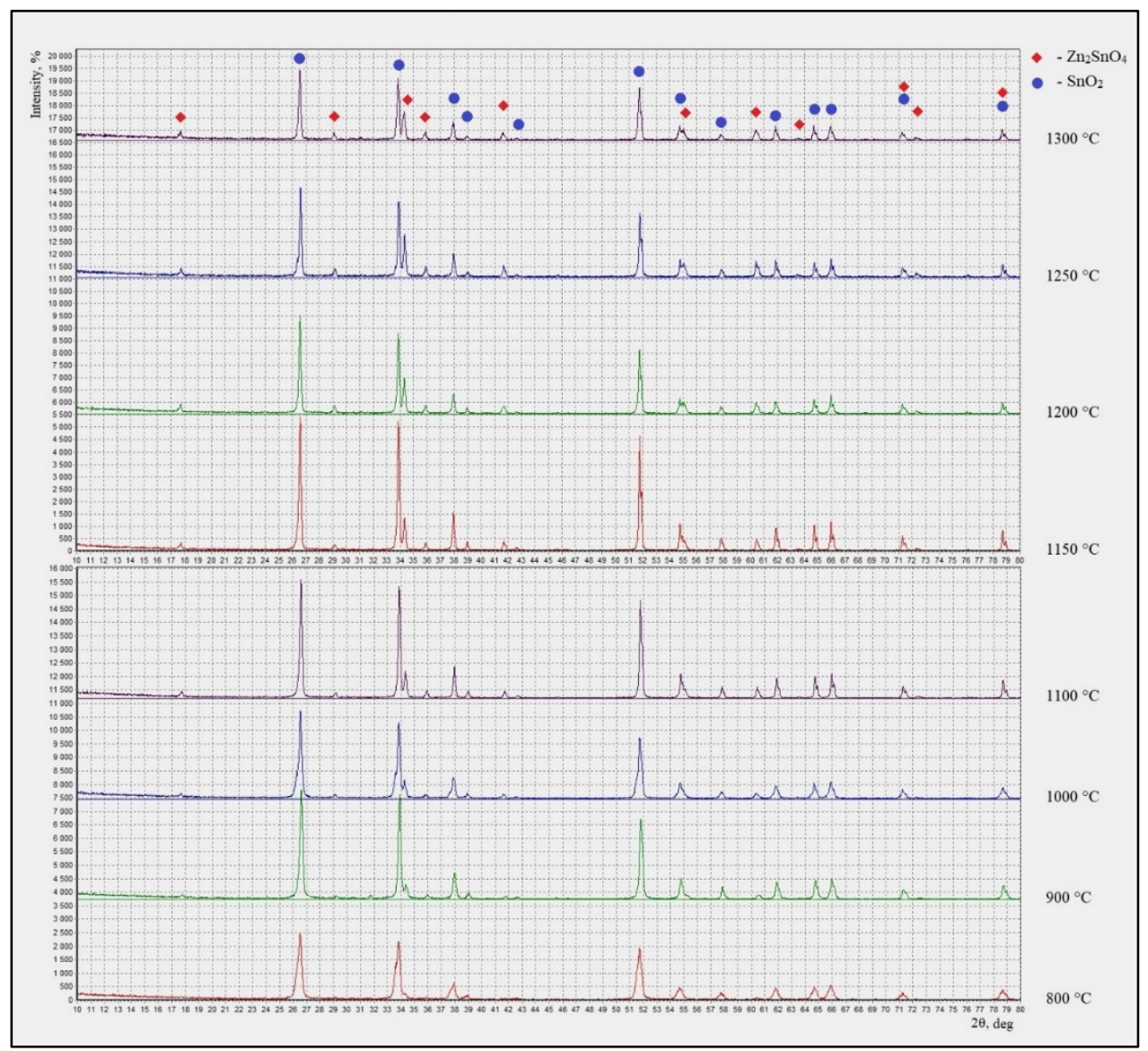

Fig. 1. XRD results for powders synthesized in the temperature range $800-1300{ }^{\circ} \mathrm{C}$, molar ratio $\mathrm{ZnO}: \mathrm{SnO}_{2}-2: 1$

Since no peaks characteristic of the zinc oxide phase are observed according to XRD data, it can be assumed that this phenomenon is associated with a deviation from stoichiometry $(\gamma-$ nonstoichiometry) [6], specifically with the formation of a solid solution of stoichiometric zinc orthostannate and zinc oxide phase. Zinc oxide has a lower diffusion coefficient than tin oxide, due to which the tin oxide diffuses into the zinc oxide lattice. As the end of the synthesis is approached, the driving force of the process decreases, as a result of which a solid solution of orthostannate is formed, enriched in zinc oxide, which no longer reacts with tin oxide. 
$\mathrm{n}$ increase in the content of zinc oxide to a ratio of 3: 1 in the initial mixture leads to the synthesis of a larger amount of zinc orthostannate and, accordingly, a decrease in tin oxide in the system. Figure 2 shows the results of X-ray phase analysis of powders with different zinc content in the initial mixture. There is a marked decrease in the peaks of tin oxide and an increase in the peaks of zinc orthostannate in the final samples. The absence of lines characteristic of zinc oxide in the diffraction pattern is explained by the fact that all the formed zinc oxide is completely consumed for the synthesis of orthostannate.

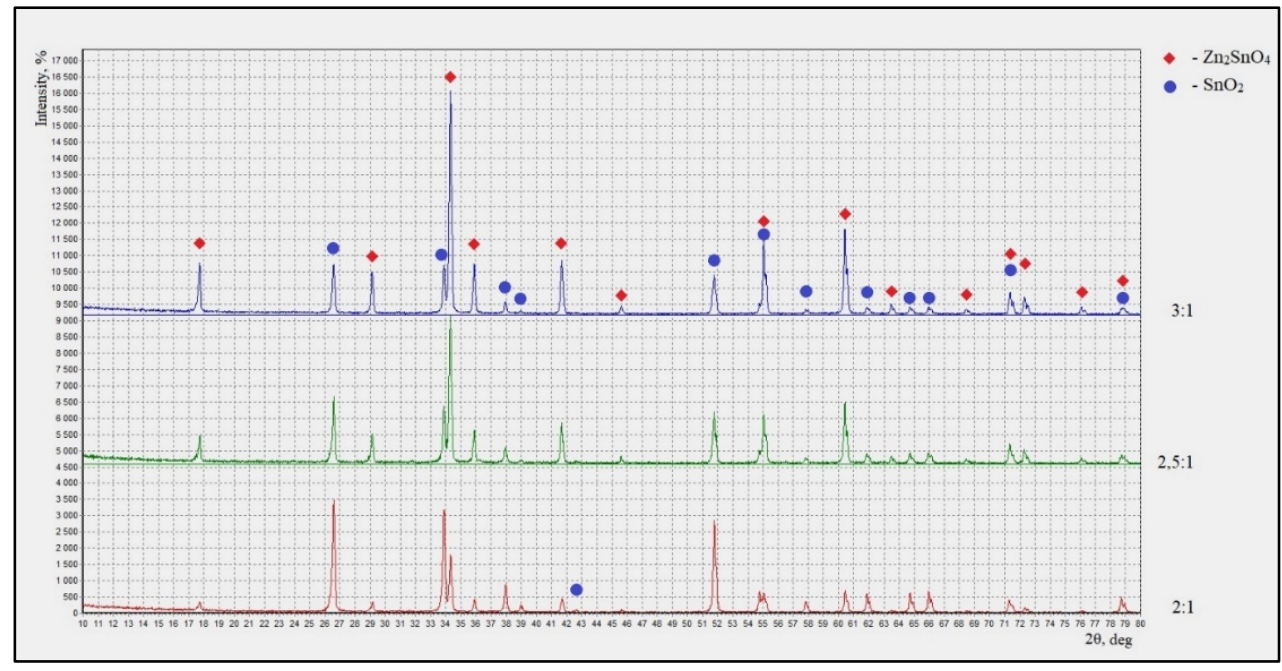

Fig. 2. XRD results for powders synthesized at temperature $1200{ }^{\circ} \mathrm{C}$, molar ratio $\mathrm{ZnO}: \mathrm{SnO}_{2}-2: 1$, $2,5: 1,3: 1$

\section{Conclusion}

In the course of the study, it was found that the formation of zinc orthostannate by heat treatment of compounds obtained by the method of coprecipitation from zinc acetate and tin (IV) chloride using ammonium carbonate as a precipitant begins at a temperature of $900{ }^{\circ} \mathrm{C}$, which is confirmed by X-ray phase analysis of the samples. According to the results of this experiment, it should be noted that an increase in the zinc content above the stoichiometric ratio of 2: 1 in the initial composition leads to a noticeable increase in zinc orthostannate in the final product, this phenomenon is associated with $\gamma$-nonstoichiometry and different diffusion coefficients of the two oxides. It is necessary to conduct further studies to optimize the ratio of components in the initial composition, to select a heat treatment mode, as well as to use other zinc salts in the co-precipitation method for the synthesis of zinc orthostannate.

\section{References}

1. Nalimova S.S., Maksimov A.I., Matyushkin L.B., Moshnikov V.A. The current state of research in the field of synthesis and application of zinc stannate // Journal of Physics and Chemistry of Glass. 2019.Vol. 45. No. 4. P. 311-325.

2. Jie Dou, Deli Shen, Yafeng Li, Antonio Abate, and Mingdeng Wei. Highly efficient perovskite solar cells based on a $\mathrm{Zn}_{2} \mathrm{SnO}_{4}$ compact layer // ACS Appl. Mater. Interfaces. 2019. 11. 40. 36553-36559/ 
3. Myung-Jin Kim, Seong-Hun Park, and Young-Duk Huh. Photocatalytic Activities of Hydrothermally Synthesized $\mathrm{Zn}_{2} \mathrm{SnO}_{4}$ // Bull. Korean Chem. Soc. 2011. Vol. 32. № 5. P. 1757.

4. Nikolić M. V., Ivetić T., Paraskevopoulos K. M., Zorbas K. T., Blagojević V., Vasiljević-Radović D. Far infrared reflection spectroscopy of $\mathrm{Zn}_{2} \mathrm{SnO}_{4}$ ceramics obtained by sintering mechanically activated $\mathrm{ZnO}-\mathrm{SnO} 2$ powder mixtures // Journal of the European Ceramic Society. 2007. Vol. 27. N. 13-15. P. 3727-3730.

5. Sidorak A.V., Shubin A.A., Ivanov V.V., Nikolaeva N.S. Synthesis of Zn2SnO4 powders by heat treatment of coprecipitated compounds // Journal of Siberian Federal University. Chemistry. 2011. T. 4. No. 3. P. 285-293.

6. Belyakov A.V. Influence of differences in the diffusion coefficients of cations on the deviation from stoichiometry in complex oxides // Glass and Ceramics. 1997. No. 10. P. 18-20. 